\title{
Kandungan Timbal pada Sala Lauak yang Dijual di Pasar Raya Padang Akibat Penggunaan Kertas Ketikan sebagai Pembungkus
}

\author{
Habifa Mulya Cita' ${ }^{1}$, Asterina ${ }^{2}$, Gestina Aliska ${ }^{3}$ \\ ${ }^{1}$ Program Studi Profesi Dokter Fakultas Kedokteran Universitas Andalas, Padang \\ ${ }^{2}$ Bagian Kimia Fakultas Kedokteran Universitas Andalas, Padang \\ ${ }^{3}$ Bagian Farmakologi Fakultas Kedokteran Universitas Andalas, Padang
}

A B S T R A C T

Latar Belakang. Timbal merupakan logam berat yang dapat memberikan efek buruk terhadap kesehatan manusia. Timbal masuk ke dalam tubuh manusia melalui saluran pernafasan, saluran cerna, dan kulit. Makanan dapat terkontaminasi oleh timbal apabila pengemasan tidak tepat, misalnya pada sala lauak yang dibungkus menggunakan kertas ketikan dapat masuk ke dalam tubuh.

Objektif. Penelitian ini bertujuan untuk membuktikan adanya kandungan timbal pada sala lauak yang dijual di Pasar Raya akibat penggunaan kertas ketikan sebagai pembungkus.

Metode. Penelitian ini bersifat deskriptif dan dilakukan di Laboratorium Air Fakultas Teknik Lingkungan Universitas Andalas pada Mei 2018 - November 2018. Jumlah sampel sebanyak 34 sampel terdiri 17 sampel sala lauak yang dibungkus kertas ketikan dan 17 sampel yang tidak dibungkus kertas ketikan dengan menggunakan teknik total sampling. Pemeriksaan sampel menggunakan alat ICP (Inductively Coupled Plasma).

Hasil. Hasil penelitian didapatkan seluruh sala lauak yang dijual pedagang di Pasar Raya Padang positif mengandung timbal, baik yang dibungkus kertas ketikan maupun yang tidak dibungkus. Rata-rata kadar timbal pada sala lauak yang dibungkus sebesar 0,172 ppm dan sala lauak yang tidak dibungkus sebesar 0,167 ppm.

Kesimpulan. seluruh sampel sala lauak mengandung logam timbal dan terdapat peningkatan kadar timbal akibat pembungkusan.

Kata kunci: logam timbal, sala lauak, kertas ketikan

Background. Lead is a heavy metal that harms human health. Lead enters the human body through the respiratory tract, gastrointestinal tract, and skin. Food can be contaminated with this substance due to the improper type of packaging such as printed paper.

Objective. This study aimed to prove the presence of lead in sala lauak sold at Padang Traditional Market due to the use of printed papers as wrappers.
Methods. A descriptive study was carried out in Water Laboratory at Faculty of Environmental Engineering Andalas University from May until November 2018. A total of thirtyfour samples were taken which consisted of seventeen sala lauak that were wrapped with printed paper and the rest wrapped without printed paper. Samples were examined by using ICP (Inductively Coupled Plasma) device.

Results. The result of this study showed that all samples contained positive lead. The amount of lead in sala lauak wrapped in the printed paper was reported higher than the unwrapped sala lauak. The average lead level in the wrapped sala lauak is $0.172 \mathrm{ppm}$ and the unwrapped sala lauak is 0.167 ppm.

Conclusion. This study concluded that all samples of sala lauak contained lead and the amount of lead was higher in sala lauak wrapped in printed paper than the unwrapped one. Keywords: lead, sala lauak, printed paper

\section{Apa yang sudah diketahui tentang topik ini?}

Makanan dapat terkontaminasi oleh timbal apabila pengemasan tidak tepat, misalnya pada sala lauak yang dibungkus menggunakan kertas ketikan dapat masuk ke dalam tubuh.

\section{Apa yang ditambahkan pada studi ini?}

Seluruh sala lauak yang dijual pedagang di Pasar Raya Padang positif mengandung timbal, baik yang dibungkus kertas ketikan maupun yang tidak dibungkus. Rata-rata kadar timbal pada sala lauak yang dibungkus sebesar 0,172 ppm dan sala lauak yang tidak dibungkus sebesar 0,167 ppm.

\section{CORRESPONDING AUTHOR}

Phone: +6285263924437

E-mail: citahabifamulya@gmail.com

\section{ARTICLE INFORMATION}

Received: March $10^{\text {th }}, 2020$

Revised: March $16^{\text {th }}, 2020$

Available online: March $20^{\text {th }}, 2020$ 


\section{Pendahuluan}

Makanan merupakan kebutuhan yang sangat penting bagi kesehatan manusia, harus diperhatikan karakteristiknya untuk setiap negara. Penyakit yang disebabkan oleh makanan dipengaruhi oleh beberapa faktor, antara lain kebiasaan mengolah makanan, penyimpanan, penyajian yang tidak bersih, dan tidak memenuhi persyaratan sanitasi. ${ }^{1}$ Salah satu makanan favorit masyarakat adalah makanan gorengan, merupakan salah satu bentuk jajanan yang masih banyak dikonsumsi. Gorengan jajanan juga berisiko terhadap kesehatan apabila dalam penjualannya tidak higienis, serta pemilihan pengemasan makanan yang kurang tepat. ${ }^{2}$

Sumatera Barat merupakan daerah yang memiliki wilayah garis pantai yang cukup panjang. Berbatasan langsung dengan Samudera Hindia menjadikan Sumatera Barat memiliki potensi tinggi akan hasil kekayaan laut, khususnya berupa ikan. Berdasarkan data dari Badan Pusat Statistik Sumatera Barat ikan merupakan penyumbang sumber protein nomor 2 setelah padi-padian di wilayah Sumatera Barat. $^{3}$ Salah satu makanan jajanan olahan ikan yang khas yaitu sala lauak. Terbuat dari bahan tepung beras kemudian dicampur dengan ikan asin dan bumbu berupa cabai, bawang merah, bawang putih, jahe, kunyit, daun bawang, daun kunyit, garam, dan air. ${ }^{4}$

Makanan yang layak dikonsumsi mempunyai beberapa kriteria yaitu berada dalam derajat kematangan yang dikehendaki, bebas dari pencemaran, perubahan fisik, kimia yang tidak dikehendaki, pengaruh enzim, aktifitas mikroba, hewan pengerat, serangga, dan kerusakankerusakan karena tekanan, pemasakan, dan pengeringan, dan bebas dari mikroorganisme dan parasit yang menimbulkan penyakit. ${ }^{5}$ Tidak hanya dilihat dari kriteria makanan saja, pemilihan jenis kemasan juga harus dipertimbangan syarat-syarat pengemasan yang baik untuk produk. ${ }^{6}$ Banyak ditemukan penjual jajanan gorengan menggunakan kertas ketikan untuk membungkus makanan dengan alasan untuk memanfaatkan kertas bekas dan harganya relatif murah dibandingkan dengan kertas baru yang masih bersih. Kertas koran maupun kertas ketikan yang digunakan tersebut mengandung zat-zat kimia yang berbahaya. Salah satu zat pencemar berbahaya yang terkandung didalam tinta ketikan adalah logam timbal.7,8 Asupan harian timbal bisa didapat melalui udara, air, dan makanan. ${ }^{9}$

Timbal atau timah hitam merupakan senyawa kimia yang banyak dimanfaatkan di industri sebagai bahan campuran bensin, bahan dasar baterai, pelapis kabel, bahan pewarna cat dan lainlain. Timbal dapat mencemari air, udara, dan tanah, sedangkan pada manusia timbal masuk dan mengendap dalam darah. Timbal masuk ke dalam tubuh manusia melalui inhalasi (pernafasan), saluran cerna atau terabsorbsi melalui kulit.10,11 Sumber timbal lainnya bisa berasal dari perindustrian dan asap kendaraan yang menggunakan bahan bakar mengandung timbal. ${ }^{10}$

Timbal dapat memberikan efek yang buruk terhadap kesehatan manusia. Timbal dapat masuk ke tubuh manusia melalui pernafasan (inhalasi), saluran cerna yang masuk melalui makanan dan minuman ataupun terabsorbsi melalui kulit. ${ }^{12}$ Efek timbal terhadap kesehatan dapat menyebabkan berbagai penyakit seperti anemia, hipertensi, epilepsi, delirium, halusinasi, penurunan konsentrasi, lesi tubulus proksimal, infertilitas, penurunan produksi sperma, penurunan libido, konstipasi atau diare. Timbal tidak hanya memberi efek kepada manusia dewasa dan anak-anak saja, bahkan janin dalam kandungan juga akan merasakan efek toksik dari timbal. Timbal dapat masuk melalui plasenta dan air susu ibu (ASI) sehingga akan menganggu perkembangan janin karena sistem organ janin yang belum bekerja optimal. Beberapa laporan pernah didapatkan bahwa keracunan timbal dapat menyebabkan koma ataupun kematian.12,13

Menurut SNI (Standar Nasional Indonesia) 7387:2009 membagi batas maksimum cemaran kadar logam pada makanan berdasarkan jenis produknya. Terdapat berbagai golongan kadar batas maksimun cemaran logam timbal pada pangan. Cemaran logam timbal mempunyai batas maksimum dalam produk makanan yaitu 0,25 mg/kg. ${ }^{14}$ Tahun 1997, Centers for Disease Control and Prevention (CDC) menetapkan bahwa nilai ambang batas (NAB) kadar timbal dalam darah adalah $10 \mu \mathrm{g} / \mathrm{dL} .^{15}$ Penelitian membuktikan bahwa penggunaan kertas bekas sebagai pembungkus makanan tidak aman karena adanya unsur timbal yang dapat lepas ke dalam makanan yang dikemas. Hasil pada penelitian tersebut deperoleh kadar timbal dalam kertas HVS $6,013 \mu \mathrm{g} / \mathrm{g}$ dan dalam tinta cetak sebesar 2,012 
$\mu \mathrm{g} / \mathrm{mL}$ serta laju pelepasan timbal ke dalam makanan gorengan sebesar 4,97 x 10-3 ppm/menit. ${ }^{8}$ Survey awal peneliti yang telah dilakukan pada penjual sala lauak di Pasar Raya Kota Padang, terdapat 17 pedagang dan 100\% masih membungkus sala lauak dengan kertas ketikan atau kertas bekas photocopy.

Berdasarkan paparan di atas menunjukkan bahwa timbal sangat berbahaya bagi tubuh dan sumber masuk utama ke dalam tubuh melalui makanan serta masih banyak penjual makanan menggunakan kertas ketikan sebagai pembungkus. Sala lauak merupakan salah satu jajanan favorit di keluarga peneliti dan jajanan yang selalu ada di lingkungan masyarakat sampai saat ini, serta peneliti mempunyai pengalaman ketika membeli sala lauak terdapat tempelan cetakan tinta tulisan yang ada di kertas ketikan pada sala lauak yang dibawa pulang. Oleh karena itu, peneliti tertarik untuk membuktikan adanya kandungan timbal yang terdapat dalam sala lauak akibat penggunaan pembungkus kertas ketikan.

\section{Metode}

Jenis penelitian ini adalah deskriptif untuk mengetahui terdapatnya kadar timbal pada sala lauak yang dijual pedagang sala lauak di Pasar Raya Padang. Penelitian dilakukan dari bulan Mei 2018 - November 2018.

Populasi penelitian ini adalah sala lauak yang dijual dari semua pedagang sala lauak di Pasar Raya Padang.

Sampel penelitian adalah sala lauak yang dibungkus dengan kertas ketikan dan sala lauak yang tidak dibungkus dengan kertas ketikan. Sampel yang tidak dibungkus dengan kertas ketikan tetap dibungkus menggunakan pembungkus yang lain yaitu plastik klip (zip lock) agar terbebas dari kontaminasi yang lain.

Sampel berupa jajanan sala lauak akan diambil dari setiap pedagang dengan menggunakan total sampling yaitu sebanyak 34 sampel dimana 17 sampel dibungkus dengan kertas ketikan dan 17 sampel lainnya tidak dibungkus dengan kertas ketikan. Sampel dikirim ke laboratorium air Fakultas teknik lingkungan Universitas Andalas untuk dilakukan pemeriksaan mengatuhui kadar timbal didalam sampel menggunakan alat Induvtively Coupled Plasma (ICP).
Hasil

Tabel 1. Hasil Kualitatif pada Sampel Sala Lauak yang Dibungkus Kertas Ketikan

\begin{tabular}{ccc}
\hline Kadar Timbal & f & \% \\
\hline Positif & 17 & $100 \%$ \\
Negatif & 0 & $0 \%$ \\
\hline Total & 17 & $100 \%$ \\
\hline
\end{tabular}

Tabel 2. Hasil Kualitatif pada Sampel Sala Lauak yang Tidak Dibungkus Kertas Ketikan

\begin{tabular}{ccc}
\hline Kadar Timbal & f & $\mathbf{\%}$ \\
\hline Positif & 17 & $100 \%$ \\
Negatif & 0 & $0 \%$ \\
\hline Total & 17 & $100 \%$ \\
\hline
\end{tabular}

Berdasarkan Tabel 1 dan 2 didapatkan hasil seluruh sampel sala lauak yang dibungkus dengan kertas ketikan maupun yang tidak dibungkus dengan kertas ketikan 100\% positif mengandung timbal.

Tabel 3. Hasil Kuantitatif pada Sampel Sala Lauak yang Dibungkus Kertas Ketikan

\begin{tabular}{cc}
\hline Sampel & Kadar Timbal (ppm) \\
\hline 1 & 0,131 \\
2 & 0,149 \\
3 & 0,161 \\
4 & 0,194 \\
5 & 0,156 \\
6 & 0,157 \\
7 & 0,165 \\
8 & 0,179 \\
9 & 0,167 \\
10 & 0,178 \\
11 & 0,163 \\
12 & 0,213 \\
13 & 0,195 \\
14 & 0,202 \\
15 & 0,165 \\
16 & 0,164 \\
17 & 0,186 \\
\hline
\end{tabular}

Tabel 4. Hasil Kuantitatif pada Sampel Sala Lauak yang Tidak Dibungkus Kertas Ketikan

\begin{tabular}{cc}
\hline Sampel & Kadar Timbal $(\mathrm{ppm})$ \\
\hline 1 & 0,126 \\
2 & 0,149 \\
3 & 0,154 \\
4 & 0,188 \\
5 & 0,157 \\
6 & 0,156 \\
7 & 0,168 \\
8 & 0,178 \\
9 & 0,161 \\
10 & 0,184 \\
11 & 0,160 \\
12 & 0,188 \\
13 & 0,195 \\
14 & 0,189 \\
15 & 0,153 \\
17 & 0,159 \\
\end{tabular}


Berdasarkan tabel 3 dan 4 terlihat perbedaan kadar timbal antara sala lauak yang dibungkus dengan kertas ketikan dengan yang tidak dibungkus kertas ketikan. Tabel 3 terlihat kadar timbal tertinggi pada sampel nomor 12 yaitu 0,213 ppm dan terendah pada sampel nomor 1 yaitu 0,131 ppm. Dilihat pada Tabel 4 kadar timbal tertinggi pada sampel nomor 13 yaitu 0,195 ppm dan terendah pada sampel nomor 1 yaitu $0,126 \mathrm{ppm}$.

Tabel 5. Rata-Rata Kandungan Timbal pada Sampel

\begin{tabular}{ccc}
\hline $\begin{array}{c}\text { Kadar timbal pada } \\
\text { sala lauak }\end{array}$ & $\begin{array}{c}\text { Mean } \pm \text { SD } \\
(\mathrm{ppm})\end{array}$ & $\begin{array}{c}\text { Kadar timbal } \\
\text { pada sala lauak }\end{array}$ \\
\hline Dibungkus & $0,172 \pm 0,021$ & Dibungkus \\
Tidak Dibungkus & $0,167 \pm 0,019$ & Tidak Dibungkus \\
\hline
\end{tabular}

Berdasarkan tabel 5 terlihat sedikit peningkatan kadar timbal antara sala lauak yang dibungkus dengan kertas ketikan maupun yang tidak dibungkus dengan kertas ketikan yaitu sebesar 0,05 ppm.

\section{Diskusi}

Berdasarkan data penelitian diketahui bahwa terdapat timbal pada sala lauak yang dibungkus menggunakan kertas ketikan maupun yang tidak dibungkus. Semua sampel positif mengandung timbal. Kandungan timbal terbesar pada sampel sala lauak yang menggunakan kertas ketikan pada sampel nomor 12 yaitu $0,213 \mathrm{ppm}$. Hal ini kemungkinan disebabkan karena tinta cetak tulisan kertas ketikan yang terpapar langsung pada sala lauak. Kandungan timbal terendah pada sampel nomor 1 yaitu 0,131 ppm. Sampel sala lauak yang tidak menggunakan kertas ketikan juga terdapat kandungan timbal, sampel nomor 13 memiliki kandungan timbal yang lebih tinggi yaitu 0,195 ppm dan sampel nomor 1 mempunyai kandungan timbal yang terendah yaitu 0,126 ppm. Didapatkan pada sampel sala lauak yang dibungkus kertas ketikan memiliki rata-rata kadar timbal sebesar 0,172 ppm dan sala lauak yang tidak dibungkus memiliki rata-rata kadar timbal sebesar 0,167 ppm. Terlihat peningkatan pada kadar timbal pada sala lauak yang dibungkus dengan kertas ketikan dengan sala lauak yang tidak menggunakan kertas ketikan sebesar 0,05 ppm.

Sala lauak yang dibungkus menggunakan kertas ketikan memiliki kadar timbal yang lebih besar dibandingkan sala lauak yang yang tidak dibungkus kertas ketikan. Hasil tersebut membuktikan bahwa terdapat pengaruh kertas ketikan terhadap kandungan logam timbal yang terdapat pada sala lauak. Hal ini kemungkinan disebabkan karena adanya kontaminasi logam berat timbal pada sala lauak yang dapat dipengaruhi oleh beberapa faktor yaitu, bahan baku yang digunakan, proses penggorengan, lamanya sala lauak yang terpapar udara, dan lamanya sala lauak yang dibungkus menggunakan pembungkus kertas ketikan. Apabila bahan baku yang digunakan sudah mengandung timbal maka kemungkinan besar hasil olahan akan mengandung timbal juga. Proses produksi juga dapat memengaruhi kualitas makanan, sehingga proses produksi harus diperhatikan juga standar hygiene dan sanitasi, seperti kebersihan peralatan yang digunakan dalam penggorengan sala lauak dan pemilihan pembungkusan yang tepat sehingga tidak membahayakan bagi para konsumen. ${ }^{16}$

Sampel diambil dari seluruh pedagang sala lauak yang ada di Pasar Raya Padang. Sala lauak yang panas setelah penggorengan dibungkus dengan kertas ketikan dan sebagai perbandingannya sampel juga dimasukkan ke dalam plastik zip lock sebagai sampel yang tidak dibungkus dengan kertas ketikan agar terhindar dari kontaminasi tambahan dari lingkungan luar. Semua sampel yang dibungkus dibiarkan 60 menit dalam bungkusan kertas ketikan, setelah itu dibawa ke laboratorium untuk pemeriksaan. Berdasarkan hasil penelitian tersebut dapat dilihat bahwa makanan yang terkontaminasi timbal itu berasal dari tinta tulisan yang ada pada kertas ketikan tersebut yang mudah terlepas dengan adanya panas dan minyak yang melarutkan tinta dan menempel pada sala lauak. Suatu penelitian membuktikan bahwa lamanya membungkus makanan menggunakan kertas koran akan mempengaruhi makanan yang dibungkus tersebut dengan ditemukannya kadar logam berat timbal sebesar $0,129 \mu \mathrm{g} / \mathrm{g}{ }^{8}$

Diketahui lokasi tempat penjual sala lauak di Pasar Raya Padang juga merupakan daerah padat lalu lintas, seperti banyaknya angkutan kota yang berhenti disekitaran penjual sala lauak untuk menunggu para penumpang, sehingga menambah salah satu faktor yang mempengaruhi terdapatnya timbal pada sala lauak. Hasil penelitian ini juga sejalan dengan penelitian yang meniliti pengaruh 
udara dari pencemaran asap kendaraan terhadap makanan rakik udang di Tapakis Ulakan Pariaman dan didapatkan rata-rata kadar timbal sebesar 0,112 ppm. ${ }^{17}$

Batas cemaran logam berat timbal dalam makanan sebesar 0,5 ppm. Hal ini menunjukkan bahwa sala lauak yang dibungkus menggunkan kertas ketikan masih aman dikonsumsi masyarakat karena masih dibawah nilai ambang batas yang sudah ditentukan, walaupun demikian pelepasan timbal dari tinta cetakan akibat proses penggorengan dengan minyak panas yang ada pada kertas ketikan tersebut sangat berbahaya bagi kesehatan masyarakat jika terkonsumsi. Timbal yang terdapat dalam makanan dalam jumlah yang banyak dan dalam jangka waktu yang lama perlu dihindari mengingat sifat timbal yang dapat terakumulasi dan mengendap didalam tubuh. ${ }^{18}$

Tubuh kita masih bisa menerima timbal dalam batas-batas tertentu. Penelitian menyebutkan bahwa Provisional Tolerable Weekly Intake (PTWI) timbal yaitu $50 \mu \mathrm{g} / \mathrm{kgBB}$ untuk anak-anak dan pada orang dewasa asupan harian timbal ditetapkan sebesar 200-300 $\mu$ g perhari. ${ }^{19}$ Menurut SNI (2009) PTWI timbal adalah $25 \mu \mathrm{g} / \mathrm{kgBB}$ atau sama dengan $0,025 \mathrm{mg} / \mathrm{kgBB}$. Bila rata-rata berat badan manusia adalah $60 \mathrm{~kg}$, maka kadar timbal yang dapat ditoleransi oleh tubuh sebanyak 1,5 $\mathrm{mg} / \mathrm{minggu}$ atau setara dengan $0,214 \mathrm{mg} /$ hari. ${ }^{20}$ Hasil penelitian terlihat bahwa rata-rata kadar timbal dalam sala lauak masih dibawah nilai PTWI yang sudah ditetapkan oleh WHO dan SNI.

\section{Kesimpulan}

Seluruh sampel sala lauak yang dijual di Pasar Raya Padang positif mengandung logam timbal, baik yang dibungkus dengan kertas ketikan maupun yang tidak dibungkus dengan kertas ketikan.

Seluruh sampel sala lauak yang diteliti memenuhi syarat dan dapat dikonsumsi karena masih berada dibawah nilai ambang batas cemaran logam yang ditetapkan oleh BPOM RI Nomor HK.00.06.1.52.4011 tahun 2009 yakni 0,5 ppm.

\section{Ucapan Terima Kasih}

Terima kasih kepada staf Laboratorium Air Teknik Lingkungan Universitas Andalas serta pihak lainnya yang telah memberikan kontribusi dalam pelaksanaan penelitian ini.

\section{Daftar Pustaka}

1. Chandra B. Pengantar Kesehatan Lingkungan. Jakarta: Penerbit Buku Kedokteran EGC, 2007.hlm.85.

2. Fitri CN. Faktor-faktor yang Berhubungan dengan Kebiasaan Konsumsi Makanan Jajanan pada Siswa Sekolah Dasar di SDN Rawamangun 01 Pagi Jakarta Timur Tahun 2012. Skripsi. Jakarta: Universitas Indonesia. 2012.hlm.1

3. Badan Pusat Statistik Provinsi Sumatera Barat. Pola Konsumsi Makanan Penduduk Sumatera Barat 20132014. Padang: BPS Provinsi Sumatera Barat. 2014.hlm.31

4. Yuliana, Yulastri A, Baidar, Faridah A. Model Perbaikan Status Gizi Balita dan Penganekaragaman Pangan Masyarakat Melalui Standarisasi dan Peningkatan Kualitas Gizi Makanan Tradisional Minang di Propinsi Sumatera Barat. Padang: Universitas Negeri Padang. 2013.hlm.30.

5. Depkes RI. Kementerian Kesehatan Republik Indonesia. Higiene dan sanitasi makanan. [Online] Januari 21, 2016. [Cited: Mei 10, 2018.] http://202.70.136.110/subdit_pp/portal/konten/ b erita/012118-makanan-sehat.

6. Julianti E, Nurminah M. Buku Ajar Teknologi Pengemasan. Medan: Departemen Teknologi Pertanian Fakultas Pertanian Universitas Sumatera Utara, 2006.hlm.7.

7. Novianti K. Bahaya Kemasan Produk Pangan. [Online] Oktober 12, 2009. [Cited: Mei 18, 2018.] http://www.bbpp-

lembang.info/index.php/arsip/artikel/artikelpertanian/110-bahaya-kemasan-produk-pangan.

8. Suwaidah IS, Achyadi, Cahyadi W. Kajian Cemaran Logam Berat Timbal dari Kemasan Kertas Bekas Ke Dalam Manakan Gorengan. Panel Gizi Makanan. edisi 2. 2014; vol. 37: 145-154.

9. Sihite HM. Analisis Kandungan Timbal pada Lipstik Impor dan Dalam Negeri Serta Tingkat Pengetahuan Konsumen dan Pedagang Terhadap Lipstik yang Beredar Di Pasar Petisah Kota Medan Tahun 2015 [Skripsi]. Medan: Fakultas Kesehatan Masyarakat USU. 2015.

10. Sudarmaji HJ, Mukono, Corie IP. Toksikologi Logam Berat dan Dampaknya Terhadap Kesehatan. 2006; 2(2): 129-142.

11. Mulyadi HJ, Mukono, Notupuro H. Paparan Timbal Udara Terhadap Timbal, Darah, Hemoglobin, Cystatin C Serum Pekerja Pengecatan Mobil. 2015; 11(1): 8795.

12. Widowati, Sastiono W, Jusuf R. Efek Toksik Logam Pencegahan dan Penanggulangan Pencemaran. Yogyakarta : CV. Andi Offset. 2008.hlm.67.

13. Laila NN, Shofwati I. Kadar Timbal Darah dan Keluhan Kesehatan pada Operator Wanita SPBU. Jurnal Kesehatan Reproduksi. 2013; 4(1): 4149.

14. Badan Standarisasi Nasional. Batas Maksimum Cemaran Logam Berat Dalam Pangan (SNI 7387:2009). Jakarta: Badan Standarisasi Nasional. 2009.hlm.8.

15. Centers for Disease Control and Prevention (CDC). NIOSH Safety and Health Topic: Adult Blood Lead Epidemiology And Surveillance (ABLES). [Online] 
2011. [Cited: Mei 17, 2018.] https://www.cdc.gov/niosh/topics/ABLES/descripti on.html.

16. Badan Pengawas Obat dan Makanan. Batas Maksimum Cemaran Kimia dalam Pangan Olahan. [Online] 2009. [Cited: Januari 14, 2019.] http://jdih.pom.go.id)

17. Angga P. Analisis Kandungan Timbal pada Gorengan yang Dijual Sekitar Pasar Ulakan Tapakis Padang Pariaman Secara Spektrofotometri Serapan Atom. 2017; vol.6(3): 490-494.

18. Palar H. Pencemaran dan toksikologi logam berat. Jakarta : Rineka Cipta. 2012.hml.74

19. Naria E. Mewaspadai Dampak Bahan Pencemaran Timbal (Pb) Di Lingkungan Terhadap Kesehatan. 2005; Vol 17(4): 66-72.

20. Badan Standarisasi Nasional. Batas Maksimum Cemaran Logam Berat dalam Pangan (SNI 7387:2009). Jakarta: Badan Standarisasi Nasional. 2009.hlm.23 